\title{
JOSEPH DE MAISTRE
}

Tekst został przetłumaczony na postawie: J. de Maistre, Pensées du comte J. de Maistre sur la religion, la philosophie, la politique, l'historie et la literature, Eduard Privat, Touluse [bdw], s. 105-114, 124-125, 129-132, 135-138.

\section{O papieżu (fragmenty)}

\section{Papieże. Supremacja dowiedziona przez historię}

Dic w historii Kościoła nie jest tak niezaprzeczalnie wykazane, zwłaszcza wobec sumienia, które nigdy nie wchodzi w dyskusje, jak wyższość Ojca Świętego. Nie od początku istniała ona w takiej formie jak w późniejszych wiekach, jednakże tak właśnie objawia się boskość: wszystko, co prawomocne i istniejące na przestrzeni stuleci, stopniowo rozwija się z zalążka.

Rzadko ośmielamy się dziś cytować teksty ustanawiające supremację Rzymu w sposób niezaprzeczalny, datowane od początków chrześcijaństwa aż po dziś dzień. Teksty te są tak dobrze wszystkim znane, iż recytując je, wydajemy się okazywać próżną erudycję.

Jak jednak zaprzeczyć, iż w dziele takim jak poniższe znajdujemy zwięzły przegląd najcenniejszych pomników najczystszej tradycji?

$\mathrm{Na}$ długo przed prześladowaniami, zanim Kościół, doskonale wolny w tym, co głosi, mógł bez przeszkód potwierdzić swą wiarę przez dostateczną liczbę rzeczywistych, namacalnych działań, Ireneusz, na mocy rozmów z uczniami apostołów, wezwał ich na tron Piotrowy, uznając to za jedną z zasad wiary i ogłaszając tę królewską wyższość, wyznawaną w całym Kościele.

Tertulian już w połowie II wieku pisał w swoim imieniu: Oto niepodważalny edykt Ojca Świętego, Biskupa Biskupów.

Święty Cyprian, po odniesieniu się do słów: ty jesteś Piotr..., dodaje: Oto, skąd wynika mianowanie biskupów i forma Kościoła.

\footnotetext{
* Pełen tekst tłumaczenia dostępny jest w drukowanej wersji pisma.
} 
Święty Grzegorz z Nyssy wyznaje tę samą doktrynę względem Wschodu: Jezus Chrystus - pisze - ofiarował biskupom, za pośrednictwem Piotra, klucze do Królestwa Niebieskiego. (...)

P R Z E ŁO ŻY ŁA M A R T A D O R E N D A 